\title{
Assessment of self-medication practices in the context of the COVID-19 outbreak in Togo
}

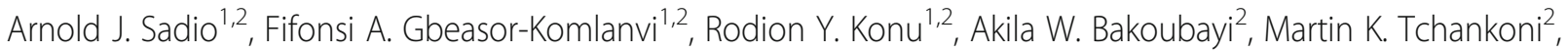
Alexandra M. Bitty-Anderson ${ }^{3}$, Iris M. Gomez², Claudia P. Denadou², Joël Anani², Harold R. Kouanfack², Innocent K. Kpeto ${ }^{4}$, Mounerou Salou ${ }^{4,5}$ and Didier K. Ekouevi ${ }^{1,2,4,6^{*}}$ (D)

\begin{abstract}
Background: To date, there is no effective treatment for COVID-19, which is a pandemic disease, caused by a novel coronavirus called SARS-CoV-2. In Togo, where four in five people practice self-medication, the absence of a cure for COVID-19 and the constant progression of the disease requires an assessment of self-medication patterns in the context of the pandemic. This study aimed to estimate the prevalence of self-medication to prevent COVID-19 and its associated factors in Lomé, Togo.

Methods: A cross-sectional study was conducted in Lomé, the capital city of Togo, from April 23rd to May 8th, 2020, with a sample of participants from five sectors: the healthcare, air transport, police, road transport and informal sectors. The participants were invited to provide information about their self-medication practices to prevent COVID-19 in the 2 weeks preceding the survey.
\end{abstract}

Results: A total of 955 participants (71.6\% men) with a median age of 36 (IQR 32-43) were included. Approximately $22.1 \%$ were in the air transport sector, $20.5 \%$ were in the police sector, and $38.7 \%$ were in the health sector. The overall prevalence of self-medication to prevent COVID-19 was $34.2 \%$ (95\% Cl: $31.2-37.3 \%)$. The most commonly used products were vitamin $C(27.6 \%)$ and traditional medicine (10.2\%). Only $2.0 \%$ of participants reported using chloroquine/hydroxychloroquine. Female sex (aOR=1.90; $p<0.001)$, work in the health sector $(a \mathrm{OR}=1.89 ; p=0.001)$, secondary education level $(\mathrm{aOR}=2.28 ; p=0.043)$ and university education level $(\mathrm{aOR}=5.11 ; p<0.001)$ were associated with self-medication.

Conclusion: One-third of the individuals in high-risk populations in Lomé practiced self-medication. Intensifying awareness campaigns is crucial to fight misinformation about alleged COVID-19 prevention products on social media.

Keywords: COVID-19, Lomé-Togo, Prevention, SARS-CoV-2, Self-medication, Traditional medicine

\footnotetext{
*Correspondence: didier.ekouevi@gmail.com

'Département de Santé Publique, Université de Lomé, Faculté des Sciences de la Santé, Lomé, Togo

${ }^{2}$ Centre Africain de Recherche en Epidémiologie et en Santé Publique (CARE

SP), Lomé, Togo

Full list of author information is available at the end of the article
}

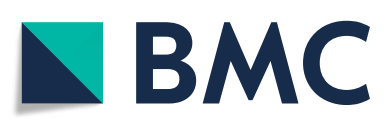

(c) The Author(s). 2021 Open Access This article is licensed under a Creative Commons Attribution 4.0 International License, which permits use, sharing, adaptation, distribution and reproduction in any medium or format, as long as you give appropriate credit to the original author(s) and the source, provide a link to the Creative Commons licence, and indicate if changes were made. The images or other third party material in this article are included in the article's Creative Commons licence, unless indicated otherwise in a credit line to the material. If material is not included in the article's Creative Commons licence and your intended use is not permitted by statutory regulation or exceeds the permitted use, you will need to obtain permission directly from the copyright holder. To view a copy of this licence, visit http://creativecommons.org/licenses/by/4.0/. The Creative Commons Public Domain Dedication waiver (http://creativecommons.org/publicdomain/zero/1.0/) applies to the data made available in this article, unless otherwise stated in a credit line to the data. 


\section{Background}

On January 30th' 2020, the World Health Organization (WHO) declared a public health emergency of international concern due to the advent in China of a disease called COVID-19 caused by a novel coronavirus, SARS$\mathrm{CoV}-2$, and its rapid spread [1]. Approximately 6 months later, almost 20 million cases and approximately 700,000 deaths have been reported worldwide [2].

To date, there is still no treatment or vaccine for this pandemic. Several studies have evaluated the efficacy of hydroxychloroquine-based treatment with or without azithromycin [3-5]. However, the efficacy of these medicines has not been proven for curative treatment of the disease. Chloroquine and hydroxychloroquine were also evaluated for prophylaxis against COVID-19 in clinical trials among close contacts of individuals diagnosed with COVID-19 and health care workers. Although the preclinical results are promising, there is currently no evidence of the effectiveness of chloroquine/ hydroxychloroquine in the prevention of COVID-19 [6].

The COVID-19 epidemic created widespread psychosis and anxiety among the population in sub-Saharan Africa [7]. This could be linked, on the one hand, to the high mortality observed in some countries, such as Italy and Spain, and on the other hand, to the lack of technical resources to combat the disease in sub-Saharan Africa. Regarding the African continent, the WHO indicated that it fears the worst, as the better resourced health-care systems of developed countries have faced enormous difficulties in dealing with the epidemic [8]. Faced with this situation and the variety of information circulating on social media, many plants and substances without the minimum requirements of efficacy and tolerance have been proposed to treat or prevent COVID19 [9]. The use of these substances without medical advice is considered self-medication, which is defined as taking medicines, herbs or home remedies on one's own initiative or on the advice of another person without consulting a medical doctor [10]. In the context of the COVID-19 pandemic, cases of poisoning and death have been reported in the USA and Nigeria in persons selfmedicating with chloroquine $[11,12]$.

Health literacy plays an important role in selfmedication behavior [13]. Concerning the COVID-19 pandemic and other coronaviruses, the level of knowledge is globally low according to a meta-analysis of 70 scientific articles. Indeed, the proportion of people with a low level of knowledge ranged from 4.3 to $57.9 \%$ among health professionals and from 4.0 to $82.5 \%$ in the rest of the population [14].

Togo, similar to most West African countries, is experiencing significant population growth (2.8\% per year): its population has more than tripled in less than 30 years, rising from 2.7 million inhabitants in 1981 to 8 ,
608,444 inhabitants in 2020 [15]. The demographic context is characterized by (i) a predominantly young population (60\% of Togolese are under 25 years old); (ii) a high population density in the coastal regions; and (iii) rapid and uncontrolled urbanization, especially in Lomé (capital) [15]. Economically, the gross domestic product per Togolese was 682 U.S. dollars in 2019, making Togo the 11th poorest country in the world [16].

In Togo, although the dispensing of psychoactive drugs is regulated by law and requires a prescription, this is not the case for other drugs, including antibiotics, which can be sold without a prescription $[17,18]$. Despite the efforts of the Togolese National Order of Pharmacists to curb the overuse and limit access to antibiotics without a prescription, these drugs are still widely consumed through self-medication [19].

Togo reported its first case of COVID-19 on March 5th' 2020, and the number of cases multiplied by ten in 3 months, with 98 cases and 6 deaths on April 26th [20] compared to 908 cases and 18 deaths on July 31st, 2020 [2]. On October 27, 2020, the country reported $264 \mathrm{cu}$ mulative cases and 6 deaths per million inhabitants [21]. The absence of a recognized treatment for the disease and its constant progression requires a re-evaluation of self-medication practices in Togo, where $80 \%$ of people resort to self-medication [22] and $60 \%$ resort to traditional pharmacopoeia [23]. Thus, this study was conducted to estimate the prevalence of preventive selfmedication and its associated factors in an epidemic context where there is no preventive or curative treatment.

\section{Methods}

\section{Study design and sampling}

This study was part of a survey aimed at describing the prevalence of SARS-CoV-2 in high-risk populations in Lomé (the capital city of Togo) [24]. This was a crosssectional study conducted from April 23rd to May 8th, 2020. A total of 955 participants were included, and the prevalence of SARS-CoV-2 was $0.7 \%$ according to polymerase chain reaction tests [24].

Participants were recruited from five professional sectors: the healthcare (doctors, nurses, pharmacy auxiliaries, and hospital administrators), air transport, police, road transport (taxi and moto-taxi drivers) and informal (market sellers and craftsmen) sectors. These groups were targeted because they are at high risk of infection during epidemics $[25,26]$. Thus, these working professionals had a high probability of being in close contact with travellers or with COVID-19 patients. Participants were eligible to participate in the study if the following four criteria were met: (i) aged $\geq 18$ years; (ii) worked in one of the five sectors under study; (iii) were regularly present at their workstation in the month prior to the 
survey, i.e., had not taken any time off work in the last 30 days and had no sick leave; and (iv) lived in Lomé for the past 3 months.

Several sampling methods were used for participant selection based on the expected total size of the target population and the availability of a sampling frame. First, exhaustive recruitment (consisting of the inclusion of all staff present at the moment of the survey) was performed among police (road safety officers) and air transport professionals (International Airport Gnassingbe Eyadema, Lomé, Togo) [24]. Second, participants from the informal sector were recruited by open invitation. Third, random sampling (two or three stages) was performed to recruit taxi and moto-taxi drivers (road transport) and health care workers [24]. For example, for the selection of moto-taxi drivers, we performed a two-stage sampling, selecting the company and then the drivers working in the company.

\section{Sample size}

The sample size was calculated using a single proportion population formula with a $95 \%$ confidence level. We hypothesized that $50 \%$ of the population would practice self-medication, with a 5\% margin error. The estimated minimum sample size was 384 participants. A $10 \%$ nonresponse rate was anticipated, and the minimum number of participants was estimated at 422 [24]. With a sample size of 955 , we reached a $3 \%$ margin error.

\section{Data collection}

After the eligibility screening and the participants' provision of written informed consent, sociodemographic characteristics, COVID-19 epidemiological data and self-medication practices were collected using a standardized questionnaire developed for this survey by a multidisciplinary team involving two medical epidemiologists, two virologists, one pharmacist and one sociologist. All sections of the questionnaire (sociodemographic characteristics; knowledge, attitudes and practices related to COVID-19; symptoms of COVID-19 and biological tests) were developed based on the data reported in the literature since the beginning of the COVID-19 pandemic. The questionnaire was tested on a sample of six medical doctors (those assumed to have the highest level of understanding) and six taxi drivers (those assumed to have the lowest level of understanding), which allowed us to reformulate or remove some questions that seemed complicated or difficult to answer. Five trained medical doctors assisted by students at the end of their medical training administered the questionnaire during a face-to-face interview. The participants were invited to give information on self-medication practices to prevent COVID-19 within the 2 weeks preceding the interview.

\section{Measurements}

Self-medication practice was the outcome variable. It was assessed based on the participants' selection and use of medicines/drugs alleged to treat or prevent COVID19 without a physician order in the past 2 weeks.

\section{Statistical analysis}

Descriptive statistics were calculated, and the results are presented as frequencies and percentages for the categorical variables. Quantitative variables are presented as medians and interquartile ranges (IQRs). The prevalence of self-medication was estimated with a $95 \%$ confidence interval (95\% CI).

Univariable and multivariable logistic model regression were performed to assess factors associated with selfmedication with the aim of preventing COVID-19. In the model building, characteristics that had a $p$-value < 0.20 in univariable analysis were considered for the full multivariable models, which were subsequently finalized using a stepwise, backward elimination approach (pvalue $<0.05$ ). This procedure allowed the estimation of adjusted odds ratios (aORs) with 95\% confidence intervals. Predictor variables were selected as those found to be relevant according to the literature review. The data analyses were performed using $\mathrm{R} \odot$ version 3.4 .3 software and the level of significance was set at $5 \%$.

\section{Ethical considerations}

Ethical approval was obtained from the 'Comité de Bioéthique de Recherche en Santé' (Bioethics Committee for Health Research) from the Togo Ministry of Health (No. 004/2020/CBRS). Potential participants were informed about the study purpose and procedures, potential risks and protections. Those willing to participate were invited to sign a consent form prior to participation.

\section{Results}

This study was a part of a survey on the prevalence of SARS-CoV-2 in populations at high risk of infection in Lomé. A total of 976 people were approached; 21 people refused to be sampled for SARS-CoV-2 and were therefore excluded from the study, for a response rate of $97.8 \%$.

\section{Sociodemographic characteristics}

In total, 955 people with a median age of 36 (IQR 32$43)$ were included in the study, and $71.6 \%(n=684)$ were men. Among the recruited participants, 38.7\% $(n=370)$ were in the health sector, $22.1 \%(n=212)$ were in the air transport sector, $20.5 \%(n=196)$ were in the police sector, $12.8 \%(n=122)$ were in the road transport sector, and $5.8 \%(n=55)$ were in the informal economy sector. None of the participants had been previously diagnosed 
as positive for COVID-19 or had been hospitalized in the last 30 days before their enrollment. Almost all of the participants $(98.0 \% ; n=936)$ were Togolese. Twothirds of the participants $(66.6 \%$; $n=636)$ were living with someone as a couple, and half $(51.0 \% ; n=487)$ of them had a university degree. The sociodemographic characteristics by professional sector are summarized in Table 1.

\section{Products used for self-medication}

Table 2 describes the products used for the prevention of COVID-19 by professional sector. The most commonly used products were vitamin $\mathrm{C}(27.6 \%)$ and traditional medicine (10.2\%). Chloroquine/ hydroxychloroquine was used by $2.0 \%$ of the sample, and azithromycin was used by $1.2 \%$.

\section{Prevalence of self-medication}

The overall prevalence of the use of at least one product to prevent COVID-19 was $34.2 \%$ (95\% CI: $31.2-37.3 \%$ ). The prevalence ranged from $16.4 \%(95 \% \mathrm{CI}=[9.8-23.0])$ for participants from the road transport sector to $51.9 \%$ (95\% $\mathrm{CI}=[46.8-57.0])$ for those from the health sector. Table 3 reports the overall self-medication prevalence by professional sector.
Factors associated with the self-medication used

In the multivariable logistic regression model, after adjustment for the other variables, three factors were positively associated with self-medication: being female $(\mathrm{aOR}=1.90 ; p<0.001)$, working in the health sector $(\mathrm{aOR}=1.89 ; p=0.001)$ and having attained a secondary or higher education level $(\mathrm{aOR}=2.28 ; p=0.043$ for secondary level and $\mathrm{aOR}=5.11 ; \mathrm{p}<0.001$ for university level). Having at least one symptom related to SARS-CoV-2 was not associated with self-medication (Fig. 1).

\section{Discussion}

The WHO does not recommend self-medication with any medicines, including antibiotics, as a form of prevention or management of COVID-19. Despite the advice of clinicians and governments, $34.2 \%$ of the people surveyed in our study used a treatment without a prescription. These treatments included modern treatments as well as traditional medicine. The prevalence of selfmedication found in our study is probably related to i) the long delay in finding an appropriate treatment for COVID-19 based on an adequately powered randomized trial [27]; ii) the influence of social media that proposes any type of product to prevent or treat COVID-19 [9]; iii) the influence of leaders (political and religious) who have claimed the efficacy of certain products or who claim to have discovered traditional remedies [28, 29];

Table 1 Sociodemographic characteristics according to sector of activity, Lomé, Togo

\begin{tabular}{|c|c|c|c|c|c|c|c|}
\hline & Health & $\begin{array}{l}\text { Air } \\
\text { transport }\end{array}$ & Police & Road transport & Informal & Total & $p$ \\
\hline & $n=370$ & $n=212$ & $n=196$ & $n=122$ & $n=55$ & $N=955$ & \\
\hline Age, $n(\%)$ & & & & & & & $0.078^{*}$ \\
\hline$<50$ & $327(88.4)$ & $178(84.0)$ & $180(91.8)$ & $101(82.8)$ & $48(87.3)$ & $834(87.3)$ & \\
\hline$\geq 50$ & $43(11.6)$ & $34(16.0)$ & $16(8.2)$ & $21(17.2)$ & $7(12.7)$ & $121(12.7)$ & \\
\hline Sex, n (\%) & & & & & & & $<0.001^{* *}$ \\
\hline Men & $181(48.9)$ & $179(84.4)$ & $168(85.7)$ & $122(100.0)$ & $34(61.8)$ & $684(71.6)$ & \\
\hline Women & $189(51.1)$ & $33(15.6)$ & $28(14.3)$ & $0(0.0)$ & $21(38.2)$ & $271(28.4)$ & \\
\hline Nationality, n (\%) & & & & & & & $0.018^{* *}$ \\
\hline Togolese & $364(98.4)$ & $205(96.7)$ & $196(100.0)$ & $119(97.5)$ & $52(94.5)$ & $936(98.0)$ & \\
\hline Others & $6(1.6)$ & $7(3.3)$ & $0(0.0)$ & $3(2.5)$ & $3(5.5)$ & $19(2.0)$ & \\
\hline In couple, n (\%) & & & & & & & $<0.001^{*}$ \\
\hline No & $169(45.7)$ & $49(23.1)$ & $49(25.0)$ & $42(34.4)$ & $10(18.2)$ & $319(33.4)$ & \\
\hline Yes & $201(54.3)$ & $163(76.9)$ & $147(75.0)$ & $80(65.6)$ & $45(81.8)$ & $636(66.6)$ & \\
\hline Education level, n (\%) & & & & & & & $<0.001^{* *}$ \\
\hline None & $5(1.4)$ & $3(1.4)$ & $0(0.0)$ & $11(9.0)$ & $5(9.1)$ & $24(2.5)$ & \\
\hline Primary & $11(3.0)$ & $2(0.9)$ & $1(0.5)$ & $26(21.3)$ & $4(7.3)$ & $44(4.6)$ & \\
\hline Secondary & 69 (18.6) & 105 (49.5) & $143(73.0)$ & $68(55.7)$ & $15(27.3)$ & $400(41.9)$ & \\
\hline University & $285(77.0)$ & $102(48.1)$ & $52(26.5)$ & 17 (13.9) & $31(56.4)$ & $487(51.0)$ & \\
\hline
\end{tabular}

${ }^{*}$ Chi square ${ }^{*}$ Fisher exact test 
Table 2 Self-medication's drugs to prevent the infection to SARS-CoV-2 according to sector of activity, Lomé, Togo

\begin{tabular}{|c|c|c|c|c|c|c|c|}
\hline & Health & $\begin{array}{l}\text { Air } \\
\text { transport }\end{array}$ & Police & Road transport & Informal & Total & $\mathbf{p}$ \\
\hline & $n=370$ & $n=212$ & $n=196$ & $n=122$ & $n=55$ & $N=955$ & \\
\hline Chloroquine/Hydroxychloroquine, n (\%) & $3(0.8)$ & $4(1.9)$ & $4(2.0)$ & $4(3.3)$ & $4(7.3)$ & $19(2.0)$ & $0.021^{* *}$ \\
\hline Azithromycin, n (\%) & $5(1.4)$ & $2(0.9)$ & $2(1.0)$ & $1(0.8)$ & $1(1.8)$ & $11(1.2)$ & $0.966^{* *}$ \\
\hline Traditional medicine, $\mathbf{n}(\%)$ & $38(10.3)$ & $19(9.0)$ & $17(8.7)$ & $12(9.8)$ & $11(20.0)$ & $97(10.2)$ & $0.155^{*}$ \\
\hline Vitamin C, n (\%) & $181(48.9)$ & $32(15.1)$ & $34(17.3)$ & $8(6.6)$ & $9(16.4)$ & $264(27.6)$ & $<0.001^{*}$ \\
\hline
\end{tabular}

* Chi square **Fisher exact test

and iv) the stigmatization of people infected with SARS$\mathrm{CoV}-2$, which encourages some people to take care of themselves at home [30].

Chloroquine/hydroxychloroquine was used by $2.0 \%$ of the population, and this proportion varied from $0.8 \%$ in people working in the health sector and $7.3 \%$ in people working in the informal sector. The use of chloroquine/ hydroxychloroquine could be linked to the fact that a study published in March 2020 concluded that hydroxychloroquine was effective for the reduction of viral load and recovery time in Covid-19 patients [5]. However, there have been many warnings about the improper use of chloroquine/hydroxychloroquine outside of hospital or clinical trial settings for COVID-19. Its use may increase the risk for arrhythmias or death [31, 32]. Political leaders such as president Trump also claimed to use chloroquine for COVID-19 prevention [28]. This type of declaration shared with the community could be destructive and nonproductive in regard to public health communication.

In our study, azithromycin was used by $1.2 \%$ of the sample. Self-medication with antibiotics such as azithromycin could cause harm to the patient and increase the risk of antimicrobial resistance [33]. The low prevalence of the use of azithromycin could be explained by its relatively high cost and by the fact that, in recent years, the Togolese pharmacists' association has insisted that these products be sold only with a prescription, even the necessity of a prescription is not regulated by law.

Table 3 Overall prevalence of self-medication ${ }^{a}$ to prevent the infection to SARS-CoV-2 according to sector of activity, Lomé, Togo

\begin{tabular}{lllll}
\hline & $\mathbf{n}$ & $\mathbf{N}$ & Prevalence (\%) & $\mathbf{9 5 C l \%}$ \\
\hline Health & 192 & 370 & 51.9 & {$[46.8-57.0]$} \\
Informal & 18 & 55 & 32.7 & {$[20.3-45.1]$} \\
Police & 49 & 196 & 25.0 & {$[18.9-31.1]$} \\
Air transport & 48 & 212 & 22.6 & {$[17.0-28.3]$} \\
Road transport & 20 & 122 & 16.4 & {$[9.8-23.0]$} \\
Total & 327 & 955 & 34.2 & {$[31.2-37.3]$} \\
\hline
\end{tabular}

${ }^{a}$ At least one of: Chloroquine/Hydroxychloroquine, Azithromycin, Traditional medicine, Vitamin C; $95 \% \mathrm{Cl}$ : $95 \%$ confidence interval
While chloroquine and hydroxychloroquine are controlled medicines that are sold in pharmacies, this is not the case for vitamin $C$. In our study, vitamin $C$ was used by approximately one-third $(27.6 \%)$ of the participants. Several studies have suggested the effectiveness of a high dose of vitamin $C$ in the management of COVID-19 [34, 35]. However, it is also important to note that high doses of vitamin $\mathrm{C}$ may cause side effects, most specifically an increased risk of kidney stones [36].

In April 2020, a traditional medicine called Covid-Organics for the prevention and treatment of COVID-19 was promoted in Madagascar [28]. However, the number of cases of COVID-19 in Madagascar quadrupled from 2214 to 10,748 in July 2020 [2, 37]. Several reasons could explain the increase in the number of cases of COVID19 , but this increase raises questions on the effectiveness of Covid-Organics, which has not yet been properly tested in therapeutic trials. Artemisia plant, the main component of Covid-Organics, has shown some beneficial effects in the treatment of malaria but has not been found to be as beneficial as artemisinin-based combination therapies (ACTs) [38]. The WHO, fearing the risk of the development of a resistance to ACTs linked to the use of this plant, does not recommend it for the treatment of malaria [38]. Furthermore, no studies have proven the efficacy for the prevention or treatment of COVID-19. In our study, one out of ten (10.2\%) participants declared that they used traditional medicine for COVID-19 prevention. This finding could be explained by the fact that the use of traditional medicine is common in African culture and relatively less expensive than modern medicines [23], although the composition of these mixtures is usually unknown [23, 39]. In regard to traditional medicine, the WHO welcomes innovations around the world, including repurposing drugs and traditional medicines and developing new therapies in the search for potential treatments for COVID-19 [9]. The WHO is working with research institutions to select traditional medicine products that can be investigated for clinical efficacy and safety for COVID-19 treatment [9].

In this study, self-medication was found to be significantly associated with being female, working in the 


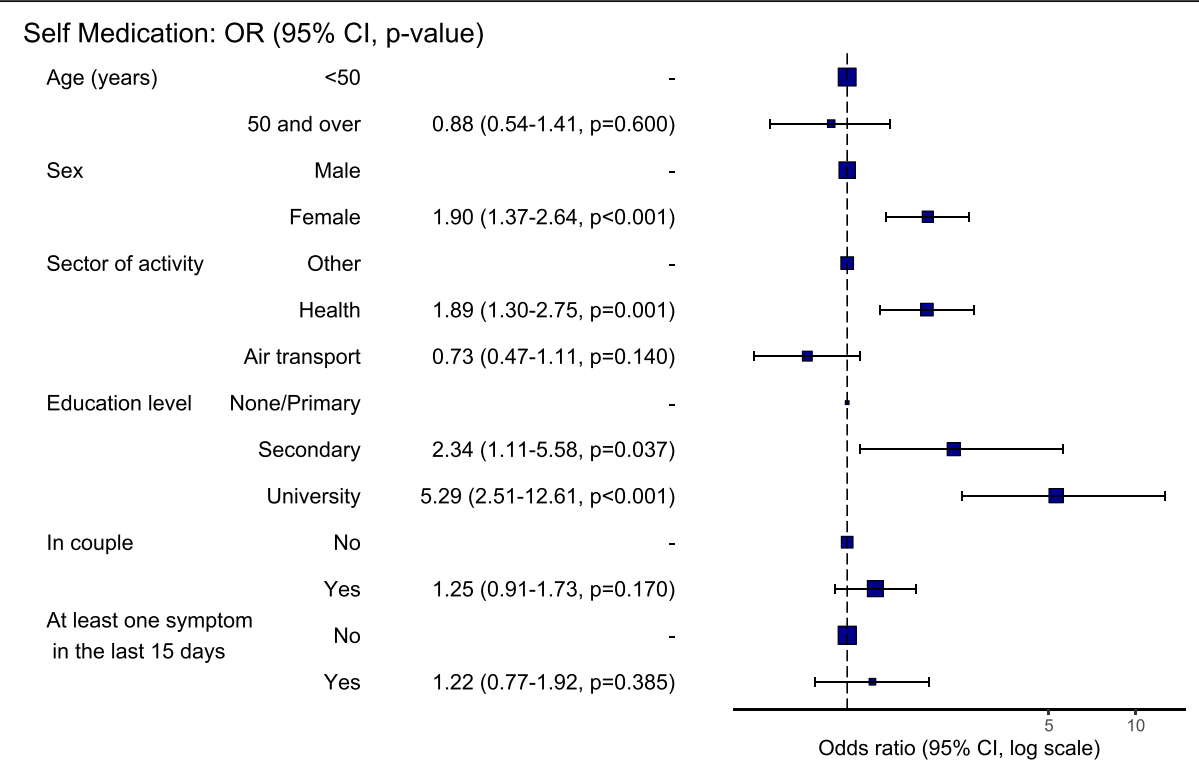

Fig. 1 shows factors associated with self-medication to prevent the infection to SARS-CoV-2 in high-risk populations, Lomé, Togo in a binary logistic multivariable model. These associations were expressed as adjusted odds ratios. Self-medication was coded as a binary variable $(=1$ if intake of at least one product and $=0$ if not)

health sector and having a high school education level or higher. There are conflicting data on the relationship between sex and self-medication [40, 41]. Some studies conducted on self-medication reported that female sex was significantly associated with self-medication. A study conducted among undergraduate students of a private university in Nigeria showed that $88.2 \%$ of females versus $71.1 \%$ of males reported using self-medication [42]. In Spain, the prevalence of self-medication was $16.93 \%$ (2715) for women and $14.46 \%$ (1469) for men $(p<0.05)$ in a study about sex differences in self-medication [43]. The reason for the association between female sex and self-medication is not clearly known, but in the context of the COVID-19 outbreak, greater anxiety among women, as described in Iran and Italy, cannot be excluded $[44,45]$.

A 2018 systematic review and meta-analysis of observational studies conducted in Ethiopia showed that healthcare professionals and students were the main practitioners of self-medication [46]. In our study, selfmedication was associated with working in the health sector. Knowledge and access to prescription-only medicines are potential factors of self-medication among health professionals. A lack of time to consult with a doctor and the desire to keep one's health status secret were also mentioned as factors that could explain selfmedication among health care personnel [47]. According to the WHO, approximately $10 \%$ of all COVID-19 cases globally are among health workers. In Africa, information on health workers' infections is still limited, but preliminary data show that health worker cases make up more than $5 \%$ of cases in 14 countries in sub-Saharan Africa alone, and in four of these countries, infections among health workers constitute more than $10 \%$ of all infections [48]. The higher risk of infection among health care professionals, their knowledge of drugs and their ease of access to drugs may also explain their higher practice of self-medication $[49,50]$.

Self-medication has often been associated with a lower education level. A study on knowledge and selfmedication with antibiotics conducted in a Lebanese adult sample reported that self-medication was significantly associated with low education level $(p=0.036)$ [51]. This was not the case for the present study conducted in the context of the COVID-19 outbreak. Indeed, participants with a high school level or higher were more likely to self-medicate. This finding could be explained by the fact that a good knowledge of diseases is known to be associated with self-medication [52-54]. The greater access of the educated population to the internet and their ability to understand information about treatment (which is often published in official languages) found on social networks may also explain this trend.

Surprisingly, a history of clinical manifestation was not associated with self-medication in our study, which confirmed the finding that self-medication was more likely to be used for the prevention of COVID-19 and not to treat specific clinical manifestations of COVID-19, which are similar to malaria symptoms.

This study has some limitations. We did not collect data on the doses of the drugs used and the length of 
time they were used. For traditional medicines, the composition of the different traditional products used was not collected. It should also be noted that in the Togolese context, traditional medicines are very often used in combination with modern medicines. Another limitation of this study is that the questionnaire used was developed entirely by our team and had never been used before. Even if the questionnaire had been pretested, biases (primacy effect, order effect, etc.) could not be excluded. Furthermore, the study was based on declarative data, which may have led to an underestimation of the prevalence of self-medication due to social desirability bias. Finally, according to the characteristics of the surveyed population (people with a high risk of SARS-CoV-2 infection), the extrapolation of these results to the general population should be performed with great caution.

\section{Conclusion}

This study was the first to assess the prevalence of selfmedication to prevent COVID-19 in Togo. Approximately one-third of people reported ever having performed self-medication. Vitamin $\mathrm{C}$ and traditional medicines were the most commonly used products. Health professionals, women and people with a high level of education were the most likely to practice selfmedication. Close collaboration is needed with pharmacists so that they will not sell chloroquine/hydroxychloroquine without a medical prescription. It is also important to fight against misinformation about supposed COVID-19 preventive products on social media with campaigns to improve awareness. Psychology is also important in COVID-19 response strategies, as reducing anxiety and ambient psychosis could reduce the use of dangerous self-medication. Studies in the general population should be conducted to confirm these results.

\section{Supplementary Information}

The online version contains supplementary material available at https://doi. org/10.1186/s12889-020-10145-1

Additional file 1. Surveillance Survey of SARS-CoV-2 Infection in Populations at Risk of Lomé-Commune in 2020: Survey sheet. This is a questionnaire developed for data collection for this study. The file is made up of two parts, an information and contact details part and a survey form part.

\section{Abbreviations \\ 95\%Cl: 95\% confidence interval; aOR: Adjusted Odds Ratio; Covid- 19: Coronavirus Disease; IQR: Interquartile range; OR: Odds Ratio; SARS-CoV- 2: Severe acute respiratory syndrome coronavirus 2; WHO: Wold Health Organization}

\section{Acknowledgements}

We are thankful to the participants who accepted to participate in this study and to the medical students of the 'Faculté des Sciences de la Santé Université de Lomé who helped to perform data collection for the study.

\section{Authors' contributions}

DKE and MS conceived the study protocol. AJS, RYK, AMB, and FAG drafted the analysis plan and wrote the first draft of the manuscript. MKT performed the statistical analysis. IKK supervised the data collection. AWB, IMG, CPD, JA, HRK collected the data. All authors contributed to data analysis through review and interpretation of the results. All authors read, revised and approved the final manuscript

\section{Funding}

This work was supported the Government of the Republic of Togo and by the "Centre Africain de Recherche en Epidémiologie et en Santé Publique de Lomé, Togo" (CARESP-Togo). The Togolese government funded the study design, data collection and data analysis. CARESP-Togo funded the data analysis and manuscript writing.

\section{Availability of data and materials}

The datasets used and/or analysed during the current study are available from the corresponding author upon reasonable request.

Ethics approval and consent to participate

This study was approved by the "Comité de Bioéthique pour la Recherche en Santé (CBRS)" (Bioethics Committee for Health Research) from the Togo Ministry of Health (CBRS N004/2020/CBRS). Potential participants were told about the study purpose and procedures, potential risks and protections, and compensation. Written informed consent was obtained prior to participation.

\section{Consent for publication}

Not applicable.

\section{Competing interests}

The authors declare that they have no competing interests.

\section{Author details}

'Département de Santé Publique, Université de Lomé, Faculté des Sciences de la Santé, Lomé, Togo. ${ }^{2}$ Centre Africain de Recherche en Epidémiologie et en Santé Publique (CARESP), Lomé, Togo. ${ }^{3}$ Programme PACCI - Site ANRS Côte d'Ivoire, CHU de Treichville, Abidjan, Côte d'Ivoire. ${ }^{4}$ Conseil Scientifique pour la riposte à la pandémie Covid-19, Lomé, Togo. ${ }^{5}$ Laboratoire de Biologie Moléculaire et d'Immunologie, Département des Sciences Fondamentales, Université de Lomé, Lomé, Togo. ${ }^{6}$ Université de Bordeaux, INSERM U1219 Bordeaux Population Health Research, ISPED, Bordeaux, France.

Received: 23 June 2020 Accepted: 28 December 2020

Published online: 06 January 2021

References

1. Al-Mandhari A, Samhouri D, Abubakar A, Brennan R. Coronavirus Disease 2019: preparedness and readiness of countries in the Eastern Mediterranean Region. East Mediterr Health J. 2020;26(2):136-7. https://doi.org/ $10.26719 / 2020.26 .2 .136$

2. World Health Organization (WHO). Coronavirus disease (COVID-19) Situation Report-193. Geneva: WHO; 2020. p. 17p. Available from: t.ly/ajoB.

3. Gao J, Tian Z, Yang X. Breakthrough: Chloroquine phosphate has shown apparent efficacy in treatment of COVID-19 associated pneumonia in clinical studies. BioScience Trends. 2020. https://doi.org/10.5582/bst.2020.01047.

4. Million M, Lagier JC, Gautret P, Colson P, Fournier PE, Amrane S. al. Early treatment of COVID-19 patients with hydroxychloroquine and azithromycin: A retrospective analysis of 1061 cases in Marseille, France. Travel Med Infect Dis. 2020:101738. https://doi.org/10.1016/j.tmaid.2020.101738.

5. Gautret P, Lagier JC, Parola P, Hoang VT, Meddeb L, Mailhe M. al. Hydroxychloroquine and azithromycin as a treatment of COVID-19: results of an open-label non-randomized clinical trial. Int J Antimicrob Agents. 2020:105949. https://doi.org/10.1016/j.ijantimicag.2020.105949.

6. Shah S, Das S, Jain A, Misra DP, Negi VS. A systematic review of the prophylactic role of chloroquine and hydroxychloroquine in coronavirus disease-19 (COVID-19) [published online ahead of print, 2020 Apr 13]. Int J Rheum Dis. 2020;10.1111/1756-185X.13842. https://doi.org/10.1111/1756$185 \times .13842$ 
7. Owings L. Africa 'not ready' for COVID-19 mental health issues. 2020 [Cited 27/05/2020]. Available from: https://is.gd/EVhGdQ.

8. Nations Unies. Covid-19: I'OMS appelle l'Afrique à se préparer au pire et à éviter les rassemblements de masse. 2020 [consulté le 04/05/2020]. Disponible sur : https://news.un.org/fr/story/2020/03/1064432.

9. World Health Organization (WHO). WHO supports scientifically-proven traditional medicine. 2020 [Cited 20/05/2020]. Available from: https://www afro.who.int/news/who-supports-scientifically-proven-traditional-medicine.

10. Hernandez-Juyol M, Job-Quesada JR. Dentistry and self-medication: A current challenge. Med Oral. 2002;7:344-7.

11. Cherian D. COVID-19: Avoid self-medication and false « cures » when battling coronavirus. 2020 [Cited 20/05/20]. Available from: https://gulfnews. com/world/americas/covid-19-avoid-self-medication-and-false-cures-whenbattling-coronavirus-1.1585042404259.

12. Busari S, Adebayo B. Nigeria records chloroquine poisoning after Trump endorses it for coronavirus treatment. 2020 [Cited 20/05/20]. Available from: https://edition.cnn.com/2020/03/23/africa/chloroquine-trump-nigeria-intl/ index.html.

13. Kamran A, Sharifirad G, Shafaeei Y, Mohebi S. Associations between Selfmedication, Health Literacy, and Self-perceived Health Status: A Community-Based Study. Int J Prev Med. 2015;6:66. https://doi.org/10.4103/ 2008-7802.161264

14. Seng JJB, Yeam CT, Huang WC, Tan NC, Low LL. Pandemic related Health literacy-A Systematic Review of literature in COVID-19, SARS and MERS pandemics. medRxiv. 2020. https://doi.org/10.1101/2020.05.07.20094227.

15. Central Intelligence Agency (CIA). The world factbook: Togo. 2020 [Cited November 18, 2020]. Available from: https://tinyurl.com/y4gafbwx.

16. Moyou E. Classement des 25 pays les plus pauvres du monde 2019 [En ligne]. 2020 [Cité le 18 Novembre 2020]. Disponible sur : https://tinyurl.com/ y5vspmho.

17. République Togolaise. Loi $\mathrm{N}^{\circ} 98-008$ portant contrôle des drogues, du 18 Mars 1998. 1998 [Cité le 31/08/2020]. Disponible sur : https://tinyurl.com/y5 gteuga.

18. Gary F, Batalha A, Tinak N. Rapport de mission d'évaluation PVS de suivi des services vétérinaires du Togo du 7 au 18 janvier 2019. Paris: Organisation Mondiale de la Santé Animale; 2019. p. 154.

19. Amede G. Togo: les pharmaciens debout contre l'usage abusif des antibiotiques. 2019 [Cité le 31/08/2020]. Disponible sur : https:/www.afriside. com/togo-les-pharmaciens-debout-contre-lusage-abusif-des-antibiotiques/.

20. République Togolaise, Site d'information officiel du Gouvernement. Coronavirus au Togo : Chiffres mis à jour. 2020 [Consulté le 27/04/2020]. Disponible sur : https://covid19.gouv.tg/.

21. World Health Organization (WHO). COVID-19 Weekly Epidemiological Update Geneva: WHO; 2020. p. 23p. Available from: https://tinyurl.com/y6o5vol9.

22. Gbeasor-Komlanvi FA, Zida-Compaore WIC, Tairou S, Ekouevi DK. Evaluation de l'automédication dans les officines de Lomé, Togo. J Rech Sci Univ Lomé. 2017:19(3):385-95.

23. Akpo-Gnandi O. Analyse du recours des populations de Lomé à la médecine traditionnelle et Projet de son intégration au système sanitaire du Togo [Thèse de Doctorat unique]. Lomé: Institut Régional d'Enseignement Supérieur et de Recherche en Développement Culturel; 2018. p. 335p.

24. Halatoko WA, Konu YR, Gbeasor-Komlanvi FA, Sadio AJ, Tchankoni MK, Komlanvi KS, et al. Prevalence of SARS-CoV-2 among high-risk populations in Lomé (Togo) in 2020. PLoS One. 2020;15(11):e0242124. https://doi.org/10. 1371/journal.pone.0242124 PMID: 33166369

25. Bernard SS, Rolland P, Silue Y, Mailles A, Campese C, Simondon A, et al. First cases of coronavirus disease 2019 (COVID-19) in France: surveillance, investigations and control measures, January 2020. Euro Surveill. 2020;25(6): 2000094. https://doi.org/10.2807/1560-7917.ES.2020.25.6.2000094.

26. Government of Canada. Risk-informed decision-making for mass gatherings during COVID-19 pandemic. 2020 [Cited at 04/03/2020]. Available from : https://tinyurl.com/y6qy968w.

27. Umscheid CA, Margolis DJ, Grossman CE. Key concepts of clinical trials: a narrative review. Postgrad Med. 2011;123(5):194-204. https://doi.org/10. 3810/pgm.2011.09.2475.

28. Baker A. Could It Work as a Cure? Maybe.' A Herbal Remedy for Coronavirus Is a Hit in Africa, But Experts Have Their Doubts. 2020 [Cited 23/05/2020]. Available from: https://time.com/5840148/coronavirus-cure-covid-organicmadagascar/.

29. Kindzeka ME. Hundreds Rush for Popular Cleric's Herbal COVID «Cure » in Cameroon. 2020 [Cited 23/05/2020]. Available from: https://www.voanews. com/covid-19-pandemic/hundreds-rush-popular-clerics-herbal-covid-curecameroon.

30. World Health Organization (WHO), United Nations of International Children's Emergency Fund (UNICEF), International Federation of Red Cross and Red Crescent Societies (IFRC). Social Stigma associated with COVID-19. Geneva: WHO, UNICEF, IFRC; 2020. p. 5p.

31. Mégarbane B. Chloroquine and hydroxychloroquine to treat COVID-19: between hope and caution. Clin Toxicol (Phila). 2020:1-2. https://doi.org/10. 1080/15563650.2020.1748194

32. Kapoor A, Pandurangi U, Arora V, Gupta A, Jaswal A, Nabar A, et al. Cardiovascular risks of hydroxychloroquine in treatment and prophylaxis of COVID-19 patients: A scientific statement from the Indian Heart Rhythm Society. Indian Pacing Electrophysiol J. 2020;50972-6292(20):30038-3. https://doi.org/10.1016/j.ipej.2020.04.003.

33. Rather IA, Kim BC, Bajpai VK, Park YH. Self-medication and antibiotic resistance: Crisis, current challenges, and prevention. Saudi J Biol Sci. 2017; 24(4):808-12. https://doi.org/10.1016/j.sjbs.2017.01.004.

34. Chu W. Hospital turns to high dose Vitamin C to fight coronavirus. 2020 [Cited 02/04/20]. Available from : https://www.nutraingredients.com/ Article/2020/03/25/Hospital-turns-to-high-dose-vitamin-C-to-fightcoronavirus?utm_source=copyright\&utm_medium=OnSite\&utm_campaign= copyright.

35. Grant WB, Lahore H, McDonnell SL, Baggerly CA, French CB, Aliano JL, Bhattoa HP. Evidence that Vitamin D Supplementation Could Reduce Risk of Influenza and COVID-19 Infections and Deaths. Nutrients. 2020;12:988.

36. Ferraro PM, Curhan GC, Gambaro G, Taylor EN. Total, Dietary, and Supplemental Vitamin C Intake and Risk of Incident Kidney Stones. Am J Kidney Dis. 2016;67(3):400-7. https://doi.org/10.1053/j.ajkd.2015.09.005.

37. World Health Organization (WHO). Coronavirus disease (COVID-19) Situation Report-163. Geneva: WHO; 2020. p. 18p. Available from: t.ly/iFMM.

38. World Health Organization (WHO), Global Malaria Programme. The use of non-pharmaceutical forms of Artemisia. Geneva: WHO; 2019. p. 21p.

39. Didier P. Automédication et pluralisme thérapeutique : la construction du choix du remède et du thérapeute dans une localité rurale à Madagascar. Anthropologie Santé. 2019; [Cité le 26/05/2020]. Disponible sur : https:// tinyurl.com/yxejy5an.

40. Abdi A, Faraji A, Dehghan F, Khatony A. Prevalence of self-medication practice among health sciences students in Kermanshah, Iran. BMC Pharmacol Toxicol. 2018;19(1):36. https://doi.org/10.1186/s40360-018-0231-4.

41. Sridhar SB, Shariff A, Dallah L, Anas D, Ayman M, Rao PG. Assessment of Nature, Reasons, and Consequences of Self-medication Practice among General Population of Ras Al-Khaimah, UAE. Int J Appl Basic Med Res. 2018; 8(1):3-8. https://doi.org/10.4103/ijabmr.IJABMR_46_17.

42. Esan DT, Fasoro AA, Odesanya OE, Esan TO, Ojo EF, Faeji CO. Assessment of Self-Medication Practices and Its Associated Factors among Undergraduates of a Private University in Nigeria. J Environ Public Health. 2018; ID 5439079. https://doi.org/10.1155/2018/5439079.

43. Carrasco-Garrido P, Hernández-Barrera V, López de Andrés A, JiménezTrujillo I, Jiménez-García R. Sex--differences on self-medication in Spain. Pharmacoepidemiol Drug Saf. 2010;19(12):1293-9. https://doi.org/10.1002/ pds.2034.

44. Moghanibashi-Mansourieh A. Assessing the anxiety level of Iranian general population during COVID-19 outbreak. Asian J Psychiatr. 2020;51:102076. https://doi.org/10.1016/j.ajp.2020.102076.

45. Casagrande M, Favieri F, Tambelli R, Forte G. The enemy who sealed the world: Effects quarantine due to the COVID-19 on sleep quality, anxiety, and psychological distress in the Italian population. Sleep Med. 2020. https://doi. org/10.1016/j.sleep.2020.05.011.

46. Sisay M, Mengistu G, Edessa D. Epidemiology of self-medication in Ethiopia: a systematic review and meta-analysis of observational studies. BMC Pharmacol Toxicol. 2018;19(1):56. https://doi.org/10.1186/s40360-018-0248-8.

47. Sado E, Kassahun E, Bayisa G, Gebre M, Tadesse A, Mosisa B. Epidemiology of self-medication with modern medicines among health care professionals in Nekemte town, western Ethiopia. BMC Res Notes. 2017;10(1):533. https:// doi.org/10.1186/s13104-017-2865-5.

48. World Health Organization, Regional office for Africa (WHO Africa). Over 10 000 health workers in Africa infected with COVID-19. 2020 [Cited 01/09/ 2020]. Available from: https://www.afro.who.int/news/over-10-000-healthworkers-africa-infected-covid-19.

49. Ran $L$, Chen X, Wang Y, Wu W, Zhang $L$, Tan X. Risk Factors of Healthcare Workers with Corona Virus Disease 2019: A Retrospective Cohort Study in a 
Designated Hospital of Wuhan in China. Clin Infect Dis. 2020;ciaa287. https://doi.org/10.1093/cid/ciaa287.

50. Jember E, Feleke A, Debie A, Asrade G. Self-medication practices and associated factors among households at Gondar town, Northwest Ethiopia: a cross-sectional study. BMC Res Notes. 2019;12(1):153. https://doi.org/10. 1186/s13104-019-4195-2 PMID: 30890186.

51. Jamhour A, El-Kheir A, Salameh P, Hanna PA, Mansour H. Antibiotic knowledge and self-medication practices in a developing country: A crosssectional study. Am J Infect Control. 2017;45(4):384-8. https://doi.org/10. 1016/j.ajic.2016.11.026.

52. Machado-Alba JE, Echeverri-Cataño LF, Londoño-Builes MJ, MorenoGutiérrez PA, Ochoa-Orozco SA, Ruiz-Villa JO. Social, cultural and economic factors associated with self-medication. Biomédica. 2014;34(4):580-8.

53. James H, Handu SS, Al khaja K, Sequeira R. Influence of medical training on self-medication by students. Int J Clin Pharmacol Therapeutics. 2008;46:23-9. https://doi.org/10.5414/CPP46023.

54. James H, Handu SS, Al Khaja KAJ, Otoom S, Sequeira RP. Evaluation of the Knowledge, Attitude and Practice of Self-Medication among First-Year Medical Students. Med Princ Pract. 2006;15:270-5. https://doi.org/10.1159/ 000092989.

\section{Publisher's Note}

Springer Nature remains neutral with regard to jurisdictional claims in published maps and institutional affiliations.

Ready to submit your research? Choose BMC and benefit from:

- fast, convenient online submission

- thorough peer review by experienced researchers in your field

- rapid publication on acceptance

- support for research data, including large and complex data types

- gold Open Access which fosters wider collaboration and increased citations

- maximum visibility for your research: over $100 \mathrm{M}$ website views per year

At BMC, research is always in progress.

Learn more biomedcentral.com/submissions 